\title{
It Is Not What Is Said, But Who Says It: Implications for Classroom Dialogic Education
}

\author{
By Motsaathebe Serekoane*
}

The principle of dialogue is the innovative teaching and learning practices with a transformative agenda. This paper argues that through dialogue lecturers can stimulate students to think and argue for themselves, rather than defer to tradition and authority. However, the context that is conducive for dialogic education, especially in a country such as South Africa that needs to come to grips with the presence of people who differ by ethnicity, class, gender, age and religion, is not known. The paper aims to share the teaching experience emanating from a lecture hall engaging in difficult topics to talk about, followed by reflection on its implication for transformative educational agenda. Emerging from the analysis of the case study is the competing dichotomy of "us" and "them". I therefore argue for a nuanced context specific process facilitation model to help participants rise above the default codes of "us" versus 'them' and look at issues in broad social contexts, irrespective of who is talking.

Keywords: dialogic education, transformative learning, "us" and "them"

\section{Introduction}

I believe that the acceptance of the teaching role at a university, particularly in anthropology, should be followed by an establishment of scholarly practice. For me this means, most importantly, a process that adopts reflexive practices (including critical self-reflection) and an understanding of the teaching and the learning context, the latter emanating from the view that challenges the one-size-fit-all assertion if we are to optimise best teaching and learning practices. Secondly, it is the acknowledgement of Palmer (2007) and McGregor's (2004) contention: we teach who we are. This phrase has taught me that my teaching comes from my identity and integrity and has challenged me to guard against residual and reproductive patterns of internalised perceptions and ideologies (from my socialisation script) that inform what I think I know of the self (in "us") in relation to the other (in "them"). Hence, my goal is to cultivate South African (and global - see Nussbaum, 2010) citizensin-the-making that are culturally responsive and able to critically engage with and reflect upon their pre-conceived norms and taken-for-granted "truths". To this extent, our education will fail our students and deprive the country of the intellectual output (both research and graduates) that can contribute to the

${ }^{*}$ Lecturer, University of Free State, South Africa. 
greater good of humanity.

The context of teaching and learning for this paper is South Africa, a country that has an unfortunate history of oppression and segregation (in neighbourhoods, schools and public interactional spaces). It is a country, although not the only one, characterized by classism, racism, sexism, ethnicism, tribalism and all the other -isms, including our not-so-liberal internalised socialisation script that choreographs a situation that legitimizes particular "frames of reference" and "habits of minds" (Mezirow, 1997:5-6). If the inherent ideologies on which all the isms are based, are not challenged through curriculum content and teaching and learning practices, then educational output is unlikely to be transformative.

I therefore deem that it is important to advocate for transformative teaching, particularly given the rigid socialization of ideas, knowledge, and perceptions about the other, and the meaning we give the other, which at the very least compromises public dialogue. This position resonates well with both the university's human project ${ }^{12}$ and the Department of Education's quest for universities that will produce students who are responsible citizens, ready to protect the democracy and promote and model social justice (DoE, 1997 now Department of Higher Education and Training [DHET]).

The urgency of the process is underscored by Boyer's (1990) seminal work on scholarship reconsideration. In this process it is important to prioritize Nussbaum's (2006) three critical abilities, (I will discuss more in detail in section "'Us' and 'them' discourse") in the scholarship of teaching and learning, if we are to deliver graduates who are not only intellectuals but also democratic and cultivated citizens. This scholarship begs for teaching and learning outcomes that incorporate Mezirow's (2003) two unique adult capabilities: critical self-reflection and reflective judgment.

In positioning transformative learning, I limit the discussion to my university context, and I treat the lecturer, students and curriculum as three critical transformative components. I have heard of academic staff members (lecturers/faculty) who want only to teach their discipline, hiding behind a façade of professionalism, ethical conduct and a scientific stance while perpetuating the taken-for-granted problematic frame of reference. I am also aware that, 22 years into democracy, our student pool does not operate from the injustice script, subscribed to it or perpetuate issues of social injustice. This negation underplays the internalized dominant hegemonic socialization script and its implication on everyday interpersonal transactions. In addition I am aware of the rigor that explains the curricular content as simply scientific. The latter view assumes that transmission of content is objective, that education does not seek to change students, and that work that challenges social injustice is merely political propaganda. I hold a contrary view and I echo the social

\footnotetext{
${ }^{1}$ Reflexivity is used in the context of this article as a tool to make sense of the "what" and "why". To engage in the moment and to understand thoughts and feelings of an experience here and now.

${ }^{2}$ The academic project aims to achieve and maintain academic excellence, and the human project aims to eradicate inequality and embrace diversity.
} 
purpose set for higher education institutions by the Department of Education: that university education, through overt curriculum, should explicitly strive for individual and ultimately societal change.

Equally importantly, I also make reference to the instrumental, communicative and emancipatory aspects of the learning process (Taylor, 2007, p. 186). Positioning myself on this typology, I argue for learning that is both communicative and emancipatory because its goal is transformative. I accept Taylor's view, which goes beyond the cognitive awareness of underlying epistemic assumptions and calls for Kolb's (1984) active experimentation so that participants can act on new understandings and acquire insights into the transformation of meaning schemes.

This is a reflexive qualitative study based primarily on a case study. Because the boundaries between students and lectures, what we hear and what was said, objectivity and subjectivity are not clearly evident, a case study approach was chosen as it would best reveal challenges of teaching a multicultural classroom. The paper draws on the teaching experience of two young lecturers (one employee of the university and another visiting scholar) with competing hegemonic identities developing from dominant positions along the axes of the "us" and "them" discourse, both espousing a transformative teaching agenda, who reflected on the dynamics of lecture hall engagement after showing a video on Izikhothane or Skhothane (street competition parading expensive clothing brands) and discussing its implications for teaching and learning in a multicultural classroom. This experience triggered a reflection on current practice, initially to make theoretical sense of it and later to draft a model (from this experience and the available literature) for its best practice.

My teaching philosophy in anthropology is underscored by asking questions, difficult questions. I argue that the kinds of questions that anthropology asks are exactly the questions that prepare students for life in post-apartheid South Africa. They are exactly the questions that disrupt the socialization narrative of childhood and create intellectual and emotional space for the inclusive dispositions that are needed to cement our young democracy. These are the very students born around 1994, after all, and what they say about differences matters. This is preparation for life in South Africa, where being able to discuss differences and handle the topic with maturity is the lifeskill that facilitates social mobility. It is because of all this that this paper argues that teaching and learning has a transformative agenda. In this paper I reflect on the implications of implementing this process in a lecture hall.

\section{Lecture Hall Seen From the First Person: A Case Study Approach}

Imagine a lecture hall that looks like almost any other: sloping rows of seats, fluorescent lighting, 300 students (of different gender, race, class and age). It is the end of class and the discussion has been a little fraught. The 
lecture has been considering Izikhotane as an emerging cultural phenomenon. Izikhotane are young people who spend vast sums of money (from an already economically stretched resource pool) on the latest fashion goods and then destroy them, sometimes going so far as to destroy money. This is a phenomenon that is hard to make sense of from outside, but many of the students have inside knowledge of it. Many think it is ridiculous, and some offence has been taken by most of the class in the 50-minute session.

Wrapping up, Jess (visiting white female lecturer) offers the example of a rich boy who is given a BMW Z3 for his $18^{\text {th }}$ birthday and promptly destroys it. Her words to the other students go something like this: "Give this some thought. What's going on here? Are the actions of Izikhotane any different to the actions of this guy?" And she adds: "Look, I don't want your take-away memory of poor black people destroying stuff. I want your thinking to go far beyond that, to what is being expressed in those actions". She is about to end the class when a black female student in the front row who I will call Mpho stands up and says furiously (and I quote from memory because the class was not recorded): "Never, never, never say black people and poverty in the same sentence. You have no right. Say poor people if you want but not poor black people. You can't say that!" The class hisses at her. Jess apologizes for offending and tries to bring attention back to the broader learning outcomes, and the disturbance subsides. After class ends, though, several students come up to Jess to express outrage at their classmate's comment, which is reassuring in some ways but Jess still feels sad, wondering if Mpho would have said the same thing or reacted similarly to Joe (hosting black male lecturer), who usually teaches the class, and does so with a frankness that almost everybody comments on. "Joe says it like it is", they often say. So why can't Jess be frank too? It's a strange lesson.

This experience led to a dialogic transaction polarized by the dichotomy of "us" and "them" and illustrating the resulting dialogic transaction of It's not what is said but who says it. In the teaching and learning context defined by "us" and "them"3, Fricker's (2008) epistemic injustice is predictable. Fricker (2008, p. 67) identifies two kinds of injustice immanent in epistemic practices. The first occurs during a testimonial transaction, "when the speaker receives a deflated degree of credibility from the hearer, owing to prejudice on the hearer's part", and he calls the second hermeneutical injustice, "occurring at a prior stage when someone is trying to make sense of a social experience but is handicapped in this by a certain gap in collective understanding", or in our case by competing positions on the continuum of either one of us or part of them. These two "elephants in the room" first the dichotomy of us and them resulting on a dialogue transaction patterned by it's not what is said but who says it,

\footnotetext{
3 "Us" and "them" in this paper refers to the in-group versus outgroup. I present it as a dichotomy that compromises dialogic education through its inherent polarisation outcome. "Us" will be anyone who does not satisfy the in-group definition of inclusion (usually along line of race, class, shared perspective and political affiliation). Everyone who is not part of the "us" becomes part of the "them". Typical exclusion disposition in a context defined by diversity.
} 
hinder dialogic transactions in a classroom with competing positions, some imagined and others real, and this poses a challenge for transformative education in South Africa.

\section{"Us" and "Them" Discourse}

In South Africa our definition and teaching practice of "transformative education" is hampered by the dichotomy of "us" and "them". These ends of the continuum compromise any effort to produce teaching and learning that aims to transform problematic frames of reference (Mezirow, 2003) that are embedded in our socialization context and reinforced by everyday codes of civility and political correctness.

The "us" and "them" discourse creates a polarized and fragile teaching context characterized by selective listening and reactive class engagement. This is counterproductive to Nussbaum's (2006, p. 388-390) three capabilities for cultivating democratic citizenship. The first capability been the capacity for "critical examination of oneself and one's tradition", which Nussbaum argues is, particularly crucial in a society that needs to come to grips with the presence of people of different religions, race and ethnicity. The second is the ability to "see oneself as not just a citizen of a particular locality but as a human being bound to all other human beings by ties of recognition and concern". This capability requires the desire to learn about nations other than one's own, but does not exclude learning about differences within one's own nation. The third is the "narrative imagination", which is the ability to imagine what it might feel like to "put oneself in another's shoes", of the one who is used to think or act completely different from oneself; elsewhere this is called empathic intelligence (Arnold, 2004). I deem all three capabilities important pillars to underscore university pedagogy in order to deliver graduates who are not only intellectuals but also democratic and cultivated citizens and to satisfy the social purpose set for a higher education institution by the Department of Higher Education and Training.

The construction of "us" and "them" is the foundation of prejudice and stereotypical perception and discourse. It starts with the labelling of the social actors and proceeds to the generalization of the negative argument to justify the exclusion of many and the inclusion of some (Wodak, 2005). In South Africa the typical coding of "us" and "them" is along the axes of differences emanating from gender, age, race and ethnicity, and economic, religious and political ideologies. My observation is that in the teaching and learning context characterised by difference, these biographical identifiers triggers competing hegemonic dispositions that reinforces the dichotomy of "us" against "them". Translating to an establishment of an argument capital that misses the credibility of the dialogue content and advances a paralysed, usually reactive argument that supports "in-point of contention" against "their-disposition".

Sinha (2010) argues that one of the many ways to optimize Nussbaum's capabilities, and bridge the gap between 'us' and 'them', our education should 
espouse dialogue as a site for transformative education for students as they encounter and address issues of social justice and differences in lecture halls. This approach is defined by Alexander (2005a; 2005b) as "collective, supportive and genuinely reciprocal; it uses carefully-structured extended exchanges to build understanding through accumulation; and throughout, children's own words, ideas, speculations and arguments featured much more prominently". This paper argues that participants in a classroom dialogue should be willing to leave their comfort zones. They should be prepared to cross borders (Dlamini, 2002) and embrace a teaching and learning opportunity that can stir and move, which can create discomfort in our quest to cultivate responsible "glocal" citizens. ${ }^{4}$

\section{Transformative Learning}

Mezirow's theory of transformative learning dating back to 1978 has received support from many scholars (among others O'Sullivan, 1999; Imel, 1998; Dirkx, 1998; O’Sullivan, Morrell, \& O'Connor, 2002; Cranton, 2006; Taylor, 2007; and Nohl, 2015). It has also been criticized (Taylor, 1997; Wang, 2008) for focusing too narrowly on individual transformation. This criticism notwithstanding, the goal of transformative learning is to effect change in a frame of reference (Mezirow, 1997, p. 5). It explains "how our expectations, framed within cultural assumptions and propositions, directly influence the meaning we derive from our experiences. A frame of reference encompasses cognitive, conative and emotional components, and is composed of two dimensions: habits of mind and points of view" (Mezirow, 1997, p. 5). Habits of mind are sets of codes informed by cultural, social, psychological or economic ideologies. An example of a habit of mind is ethnocentrism, the tendency to regard others outside one's group as inferior (Nanda \& Warms, 2014 , p. 12), resulting in a complex interactional transaction underpinned by judgmental beliefs and a negative attitude towards others. In our context the disposition is informed by biographical identity markers, especially class, race and political affiliation. Unlike "habits of mind, points of view are subject to continual change as we reflect on either the content or process by which we solve problems and identify the need to modify assumptions" (Mezirow, 1997, p. 6). This happens when we try to understand things that do not work the way we anticipated, which leads us to revise our meaning structure and transform our perspectives on the basis of experience. Undeniably, this is more ideal than real, particularly in a context that has established structures in a place that discourages thinking outside of socialisation parameters opting to reinforce compliance and to punish non-compliance. Important to note is that the revision of a new meaning is preceded by teaching that creates dissonance, but the ultimate transformation is impeded by competition with institutional practices of family, church etc. that re-affirm the taken-for-granted truths even if the reality proves otherwise.

\footnotetext{
4 "Glocal" means reflecting or characterized by both global and local considerations.
} 
Notwithstanding the context specific challenges, Mezirow (2003, p. 59) put forward a key proposition for the transformative learning theory as that which recognizes the validity of Habermas's (1984) position on the difference between instrumental and communicative learning. Instrumental learning is about acquiring skills and knowledge (essentially the how and the what). If this learning is based on a problematic frame of reference it cannot produce reflective learning. Communicative learning, on the other hand, is about transforming perspectives; it is a paradigm shift whereby we critically examine our prior interpretations and assumptions to form new meaning (the why). Central to this process is dialogue. In contemporary language, "dialogue" may then be interpreted as a "stream of meaning flowing among and through us and between us" (Bohm, 1996, p. 7). For the purpose of this paper dialogue is defined as "exchange of potentially conflicting and contradictory ideas, opinions, beliefs or values about concepts such as race, racism, homophobia and ethnicity" (Watt, 2007, p. 116). It is further complicated by who is speaking (identity markers, like race, gender, age, social status etc.) and who is listening.

The immediate challenge that precedes the dialogic educational engagement is collapsing the compound binaries of "us" versus "them". A communication context characterised by these dichotomy choreograph dialogic exchange that is obsessed with civility and liberal stances. It lacks the spark of genuine and authentic interpersonal communication transactions. In such a context, in-group (us) speaks with authority (qualified by societal status, level of education and association) while the outgroup genre is labelled problematic, lacks depth and usually discredited. If we are to achieve the outcome of communicative learning ${ }^{5}$, the paper argues for an adoption of the Boler and Zembylas, (2003) pedagogy of discomfort and mutual vulnerability (Kwenda, 2003, Keet, Zinn, \& Porteus, 2009). Both pedagogical positions challenge dialogue participants to acknowledging that what we thought we knew about the other in relation to the self (usually informed by what we were taught by institutional establishments of our respective socialisation) is wrong and beg for a dialogic space that levels the communication ground and advance joint reconstruction of new meaning.

This paper aligns itself with communicative learning in order to advance emancipatory output. In order to unlock transformative possibilities, it is critical to create an interactional space in which to engage in dialogic educational transaction. Sihna (2010, p. 459) argues for a space that encourages participants to "move from idiosyncratic responses and interpretation to more socially conscious and aware ones, that is, responses and interpretation that go beyond one's original frames of reference". Such a space will be one where people are confronted with difference, with that which is not just the self or the same. Inevitable in transformative learning is engaging in transformative

\footnotetext{
${ }^{5}$ In which actors in dialogue seek to reach common understanding and to coordinate actions by reasoned argument, consensus, and cooperation rather than strategic action strictly in pursuit of their own goals (Habermas, 1984, p. 86).
} 
pedagogy (Mezirow, 2003; Ukpokodu, 2009) and the process is illustrated by Figure 1.

Figure 1. The Process of Transformative Learning

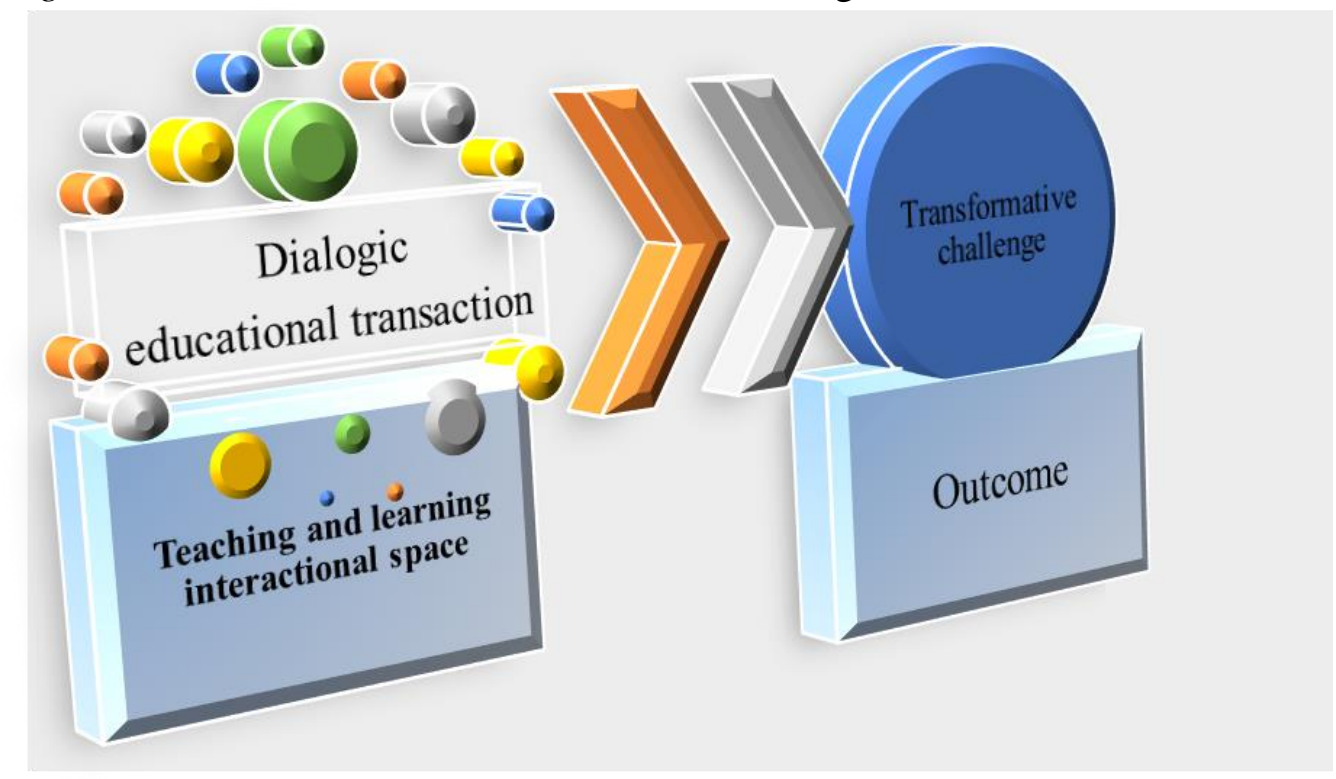

Source: Prepared by Author.

My aim in espousing transformative pedagogies is to establish a democratic and emancipatory learning context where students and teachers engage in dialogic educational transactions as co-learners, valuing each other's knowledge, and empowering each other for a negotiated transformative outcome (see Figure 1). In order to achieve this I propose the model in Figure 2 to guide the teaching and learning process. 
Figure 2. Transformative Learning Quadrants for Cultivating Responsible "Glocal" Citizen

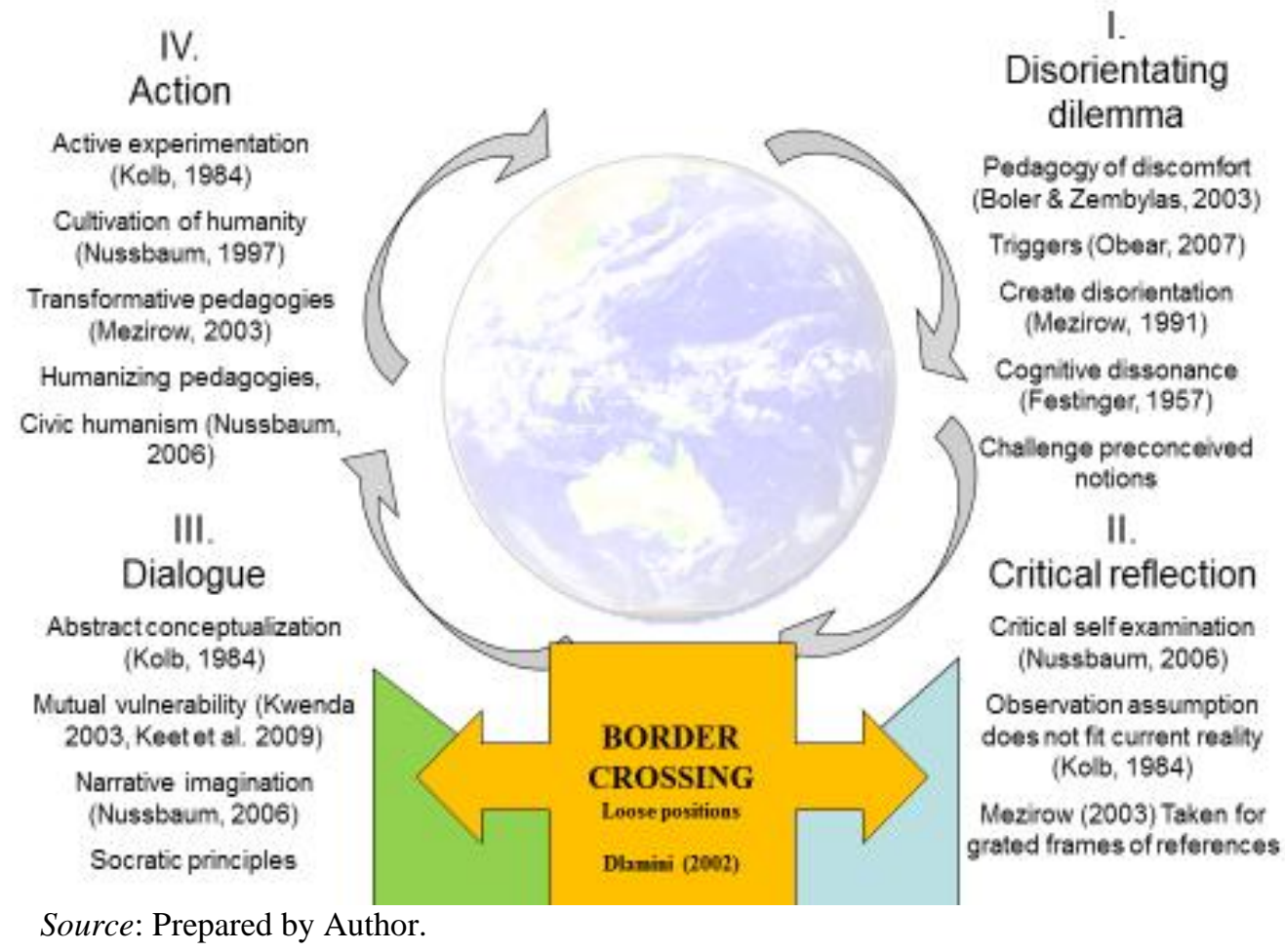

Mezirow (1981, p. 7) argues that transformation often happens in the following phases: 1. disorientating dilemmas, 2. critical reflection, 3. rational dialogue and 4. action (Figure 2). I am aware of the initially limited scope of testing of Mezirow's phases and I draw strength from later research that has tested them further across formal and informal groups and different social groups (Taylor and Cranton, 2012). I regard the first three phases as underscoring the teaching and learning interaction space (see Figure 1) and I see the fourth phase, action, as referring to the outcome (see Figure 1) where students see the world in a new light and gain new perspectives on the self, others, and the new teaching praxis (which I consider the authentic union of action and reflection).

I deem key elements of transformational learning as discussed by Mezirow (1978) to be essential to drive dialogic educational transaction (see Figure 1). This starts with a disorienting dilemma, representing a moment of dissonance, usually emanating from an experience that does not fit with pre-existing meaning structures (see Figure 2). I suggest espousing Boler and Zembylas's (2003) "pedagogy of discomfort" approaches to facilitate the interaction. This pedagogy challenges both educators and students to move out of their comfort zones and reflect critically on their own traditions and beliefs (cf. Nussbaum, 2010; Mezirow, 2003). Boler and Zembylas (2003, p. 110-111) emphasize that 
it requires both cognitive and emotional effort, perhaps exertion, to facilitate reflective judgment, especially given the recognition and problematization of the deeply embedded emotional dimensions that frame and shape daily transactions, and caution that inherent in this pedagogy are "feelings of anger, grief, disappointment and resistance".

This phase is followed by two stages that make up the theme of critical reflection (Mezirow, 1990): self-examination, accompanied by feelings of guilt or shame, and critical assessment of epistemic and socio-cultural assumptions that inform the participants' taken-for-granted frames of reference (Mezirow, 2003; Nussbaum, 2006). I acknowledge the sensitive nature of this phase and recommend a nuanced approach if we are to successfully cross borders (Dlamini, 2002). At this stage we may win or lose some of the participants. The overall aim of this process is to transform individual meaning and perspectives (Kitchenham, 2008, p. 115). I regard Mezirow's (1995 quoted in Kitchenham, 2008, p. 115) three types of reflection as important to guide this process, namely, "content reflection" (learning with present meaning schemes), "process reflection" (learning new meaning schemes) and "premise reflection" (learning through meaning transformation). Both content and process reflection will strive to transform a meaning scheme, and premise reflection is akin to critical examination of one's internalized assumptions, where participants examine their world view in the light of their own particular belief or value system.

The next stage represents the third phase of the transformative learning theory: rational discourse, alternatively dialogue. This phase involves recognition that one's discontent and the process of transformation are shared and that others have negotiated a similar change. The approach I recommend for facilitating transformative dialogue involves mutual vulnerability (Kwenda, 2003; Keet, Zinn, \& Porteus, 2009) underlined by Socratic principles. Two related discourses, abstract conceptualization (Kolb, 1984) and narrative imagination (Nussbaum, 2006), are important in order to transform the participants' meaning schemes and perspectives. This phase essentially requires a shift in position and a quest to explore with others the newly discovered misfit, emanating from one's own premises and environment. This process ensues the exploration of options for new roles, relationships and action (Dirkx, 2001).

Action, the fourth phase of the transformative learning theory, requires us to plan a course for acquiring the knowledge and skills to implement one's plan, provisionally trying new roles. Kolb (1984) describes this as active experimentation, building competence and confidence in new roles and relationships, integrating civic humanist principles into one's life and cultivating humanity (Nussbaum, 1997). It is important to optimize mutual humanization in a dialogic approach which challenges everyone ultimately to develop critical consciousness.

I think this process facilitation model will help participants to rise above the default codes of "us" versus "them" and look at issues in broad social contexts, irrespective of who is talking. It will challenge their abilities for deep, 
reflective and critical inquiry, and prompt them to consider multiple viewpoints and perspectives constructively in dialogue with others, while engaging in socially just actions as a way to prepare a new citizen for our increasingly pluralistic democracy (Zuniga, Nagda, \& Sevig, 2002; Nagda, Gurin, \& Lopez, 2003).

\section{Conclusion}

The primary aim of this paper was to share teaching experience from a multicultural classroom ambient, discussing issues that are difficult to talk about. Secondary was to reflect on current practices, initially to make theoretical sense of them and later to draft a model (from this experience and the available literature) for the best practice. Ultimately, to stimulate debate about engaging in topics difficult to talk about, especially in a teaching context characterised by diversity. This paper described a dialogic approach, underscored by the transformative theory, to teaching and learning as a way to improve the transformative capacity of both teacher and students in a multicultural lecture hall, where participants were encouraged to move beyond their original frames of reference and test their response to difference. At the heart of transformative learning is the quest to challenging existing meaningmaking structures, and to fundamentally change the perspectives or frames of references. This is particularly important for a country like South Africa that is still grappling with the aftermath of apartheid, social injustices and concomitant scars. This is a sensitive topic. I am discussing a situation where the students' backgrounds trigger the dichotomy of "us" and "them" and this can compromise the credibility of what is being said, resulting in a polarized dialogic transaction characterized by in-group versus out-group. In this kind of dialogue, it is not what is said but who says it. This dynamic reinforces and often perpetuates competing ideological positions that may ultimately compromise efforts to engage in dialogue. It poses a challenge to the transformation outcome we hope to achieve with our education, even in the most basic form.

The aforementioned does not aim to encourage despondency; it is an acknowledgment of the entanglement of embedded reinforced polarised positions. A university is a central education space with the capacity to bring people together in order to form a learning community. It is the aim of university training to advance the purpose set by the Department of Higher Education and Training. However, the university's effort is up against dynamics of everyday transactional exchanges that have embedded structural origins; that stem from internalised taken-for-granted problematic frames of references and further complicated by competing hegemonic identity markers. It remains difficult to work with internalised habits of minds and frames of references. I deem transformative learning to hold potential to make individual participants aware of holding a limiting or distorted view of the self in relation 
to the other. Transformative teaching and learning context provide an opportunity for the individual to critically examine internalised views, explore alternatives and ultimately adjust embedded meanings making structures in order to change the way he/she sees the world.

It is on account of the aforementioned that I support Mezirow's view of transformative learning as more than an educational practice or technique but as a pedagogical discourse. My evidence for this prerogative comes, in part, from my student years. As I reflect on how I was taught and what I was taught, I realised the reproduction of a thinking pattern that meant to rationalise and created no space for dialogue. So the expectation was "I teach, you listen and internalise". Teaching was reduced to an intellectual exercise and it became a cold redundant abstraction. As a lecturer in anthropology, I wrote a teaching philosophy that aims to advance educational leadership underscored by activism and advocacy. What this means is teachings that serve both the intellectual and social purpose, and I found the nexus in transformative pedagogy, particularly its epistemological potential to transform frames of references (mind-sets, habits of mind, meaning perspective) and challenging for metacognitive reasoning. With regard to latter as I understand it, is a metacognitive epistemology of evidential (instrumental) and dialogical (communicative) reasoning. Furthermore, I add to the call to optimize transformative learning as an essential part of higher education teaching and learning, such that those participating in the process can become autonomous thinkers by learning to negotiate their own values, meanings and purpose rather than deferring to old socialization scripts and acting on those of others.

Adopting this approach as practice for university teaching and learning (Moore, 2005) begs for a context that is ready for transformative education. I put forward a teaching and learning context characterised by difference as an ideal site for transformational output.

The study has some limitations and possible future research. First, because the paper followed a case study method and only one class was involved, the generalisability of the arguments from the paper is questionable. Furthermore, while the theoretical and methodological principles discussed are universal, South African dynamics will not necessary translate elsewhere. So the impact felt here may not be the same in another multicultural classroom. The paper reveals opportunities for further inquiry. One interesting theme for further exploration is to test how the "us" and "them" would play itself out in a homogenous group. In particular I am intrigued by how the participants will respond to the assumption of sameness. Another area of investigation is to explore the possibility of pedagogical underpinnings of "us" and "them" and the epistemic encounter of "it is not what is said but who says it".

\section{Acknowledgments}

Ms. JM (Jess) Auerbach, visiting PhD candidate Stanford University 


\section{References}

Alexander, R.J. (2005a). Teaching through Dialogue: the first year. London: Barking and Dagenham Council. Retrieved from: bit.ly/1SH7Ifn.

Alexander, R.J. (2005b). Towards dialogic teaching: rethinking classroom talk. York: Dialogos. Retrieved from: bit.ly/1Jxj56Uv.

Arnold, R. (2004). Empathic Intelligence: The phenomenon of inter-subjectivity engagement. Paper presented at Annual Conference of Australian Association for Research and Education. Retrieved Decenber 15, 2015 from: bit.ly/23nuzjK.

Bohm, D. (1996). On Dialogue. London and New York: Routledge Classics.

Boyer, E.L. (1990). Scholarship reconsidered: Priorities of the professoriate. Princeton, NJ: Carnegie Foundation for the Advancement of Teaching.

Boler, M., \& Zembylas, M. (2003). Discomforting truths: The emotional terrain of understanding difference. In P. Trifonas (Ed.), Pedagogies of Difference: Rethinking Education for Social Change (pp.110-136). New York: Routledge Falmer.

Cranton, P. (2006). Understanding and promoting transformative learning ( $2^{\text {nd }}$ ed.). San Francisco: Jossey-Bass.

Dirkx, J.M. (1998). Transformative learning theory in the practice of adult education: An overview. PAACE Journal of Lifelong Learning, 7, 1-14.

Dirkx, J.M. (2001). The power of feelings: Emotion, imagination, and the construction of meaning in adult learning. New Directions for Adult and Continuing Education, 89, 63-72. doi: 10.1002/ace.9

Dlamini, S.N. (2002). From the other side of the desk: Notes on teaching about race when racialized. Race, Ethnicity, and Education, 5, 51-66.

DoE (Department of Education, South Africa). (1997). Education White Paper 3: A Programme for Higher Education Transformation. Retrieved July 22, 2012 from bit.ly/1nj8wtu.

Fricker, M. (2008). Epistemic injustice: Power and the ethics of knowing. THEORIA, $61,69-71$.

Habermas, J. (1984). The theory of communicative action, reason and rationalization of society. (T. McCarthy, Trans.). Boston: Beacon Press.

Imel, S. (1998). Transformative learning in adulthood. Washington, DC: Office of Educational Research and Improvement. (ERIC Document Reproduction Service No. ED42326). Retrieved March 24, 2015 from bit.ly/1PvfY1K.

Keet, A., Zinn, D., \& Porteus, K. (2009). Mutual vulnerability: A key principle in a humanising pedagogy in post-conflict societies. Perspectives in Education, 27(2), 109-119. Retrieved from bit.ly/10RyLP5.

Kitchenham, A. (2008). The evolution of John Mezirow's transformative learning theory. Journal of Transformative Education, 6(2), 104-123. doi: $10.1177 / 1541344608322678$.

Kolb, D.A. (1984). Experiential Learning: Experiences as the Source of Learning and Development. New York: Prentice Hall.

Kwenda, C.V. (2003). Cultural justice: The pathway to reconciliation and social cohesion. In D. Chidester, P. Dexter, \& W. James (Eds.), What Holds Us Together: Social Cohesion in South Africa (pp. 67-80). Cape Town: HSRC (Human Sciences Research Council) Press.

McGregor, S.L.T. (2004). Transformative learning: We teach who we are. Kappa Omicron Nu Forum, 14(2). Retrieved June 2, 2014 from bit.ly/1QuYjpG. 
Mezirow, J. (1978). Perspective transformation. Adult Education Quarterly, 28, 100 110. doi: $10.1177 / 074171367802800202$.

Mezirow, J. (1981). A critical theory of adult learning education. Adult Education Quarterly, 32, 3-24. doi: 10.1177/074171368103200101.

Mezirow, J. (1990). How critical reflection triggers transformative learning. In J. Mezirow (Ed.), Fostering Critical Reflection in Adulthood (pp. 1-20). Jossey-Bass Publishers, San Fransisco.

Mezirow, J. (1995). Transformation theory of adult leaning. In M.R. Welton (Ed.), In Defense of the Lifeworld (pp. 39-70). New York: SUNY Press.

Mezirow, J. (1997). Transformative learning: Theory to practice. New Directions for Adult and Continuing Education, 74, 5-12. doi: 10.1002/ace.7401.

Mezirow, J. (2003). Transformative learning as discourse. Journal of Transformative Education, 1, 58-63. doi: 10.1177/1541344603252172.

Moore, J. (2005). Is higher education ready for transformative learning? A question explored in the study of sustainability. Journal of Transformative Education, 3, 76-91. doi: 10.1177/1541344604270862.

Nagda, B.A., Gurin, P., and Lopez, G.E. (2003). Transformative pedagogy for democracy and social justice. Race, Ethnicity and Education, 6(2), 165-191.

Nanda, S. and Warms, R.L. (2014). Cultural Anthropology: South African Edition. Wadsworth: Cengage Learning.

Nohl, A.-M. (2015). Typical phases of transformative learning: A practice-based model. Adult Education Quarterly, 65(1), 35-49. doi: 10.1177/0741713614558582.

Nussbaum, M.C. (1997). Cultivating humanity: A classical defense of reform in liberal education. Cambridge, MA: Harvard University Press.

Nussbaum, M.C. (2006). Education and democratic citizenship: Capabilities and quality education. Journal of Human Development, 7, 385-395. doi: 10.1080/14649880600815974.

Nussbaum, M.C. (2010). Why democracy needs the humanities. Princeton, NJ: Princeton University Press.

O'Sullivan, E.V. (1999). Transformative learning: educational vision for the 21st century. London: Zed Books.

O'Sullivan, E.V., Morrell, A., \& O'Connor, M.A. (Eds.), (2002). Expanding the boundaries of transformative learning: essays on theory and practice. New York: Palgrave.

Palmer, P. (2007). The courage to teach. Exploring the inner landscape of a teacher's life. San Francisco: Jossey-Bass Publishers.

Sihna, S. (2010). Dialogue as a site of transformative possibility. Studies in Philosophy and Education, 29(5), 459-475. doi 10.1007/s11217-010-9189-4.

Taylor, E.W. (1997). Building upon theoretical debate: A critical review of the empirical studies of Mezirow's transformative learning theory. Adult Education Quarterly, 48, 32-57. doi: 10.1177/074171369704800104.

Taylor, E.W. (2007). An update of transformative learning theory: A critical review of empirical research (1999-2005). International Journal of Lifelong Education, 26(2), 173-191. doi: 10.1080/02601370701219475.

Taylor, E.W., \& Cranton, P. (Eds.). (2012). The handbook of transformative learning. San Francisco, CA: Jossey-Bass.

Ukpokodu, O.N. (2009). Pedagogies that foster transformative learning in a multicultural education course: A reflection. Digital Scholarship, 4(1), 1-9. Retrieved November 10, 2014 from http://bit.ly/23nwq8c. doi: 10.9741/21612978.1003. 
Wang, V.C.X. (2008). Transformative learning. In L. Tomei (Ed.), Encyclopedia of Information Technology Curriculum Integration (pp. 913-917). Hershey, PA: Information Science Reference. Retrieved March 23, 2015 from http://bit.ly/23nwq8c. doi:10.4018/978-1-59904-881-9.ch143.

Watt, S.K. (2007). Difficult dialogues, privilege and social justice: Uses of the privilege identity exploration model in student affairs practice. The College Student Journal, Special Issue, 26, 114-126

Wodak, R. (2005). Understanding and explaining social change: "Deja-vu". International Journal of Applied Linguistics, 15(2), 240-243. doi: 10.1111/j.14734192.2005.00089.x

Zuniga, X., Nagda, B.A., \& Sevig, T.D. (2002). Intergroup dialogues: An educational model for cultivating engagement across differences. Equity and Excellence in Education, 35, 7-17. 
